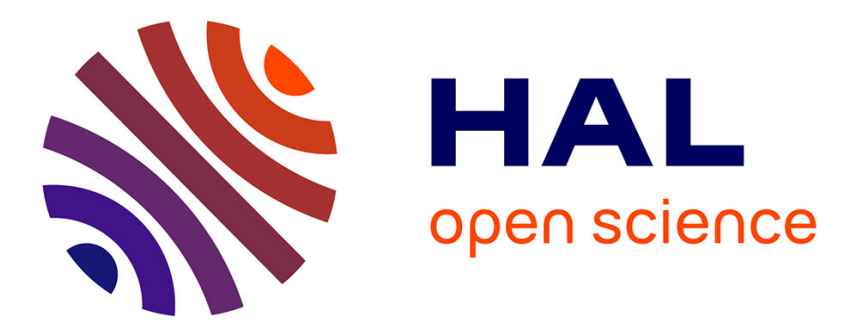

\title{
Pituitary and plasma gonadotrophin levels and spermatogenesis in the goldfish Carassius auratus after methallibure treatment
}

\author{
Bernard Breton, Bernard Jalabert, Roland Billard
}

\section{- To cite this version:}

Bernard Breton, Bernard Jalabert, Roland Billard. Pituitary and plasma gonadotrophin levels and spermatogenesis in the goldfish Carassius auratus after methallibure treatment. Journal of Endocrinology, 1973, 59 (3), pp.415-420. 10.1677/joe.0.0590415 . hal-01600384

\section{HAL Id: hal-01600384 \\ https://hal.science/hal-01600384}

Submitted on 2 Jun 2020

HAL is a multi-disciplinary open access archive for the deposit and dissemination of scientific research documents, whether they are published or not. The documents may come from teaching and research institutions in France or abroad, or from public or private research centers.
L'archive ouverte pluridisciplinaire HAL, est destinée au dépôt et à la diffusion de documents scientifiques de niveau recherche, publiés ou non, émanant des établissements d'enseignement et de recherche français ou étrangers, des laboratoires publics ou privés. 


\title{
PITUITARY AND PLASMA GONADOTROPHIN LEVELS AND SPERMATOGENESIS IN THE GOLDFISH CARASSIUS AURATUS AFTER METHALLIBURE TREATMENT
}

\author{
B. BRETON, B. JALABERT AND R. BILLARD \\ Laboratoire de Physiologie des Poissons, Institut National de la \\ Recherche Agronomique, 78350 Jouy-en-Josas, France
}

(Received 13 December 1972)

\begin{abstract}
SUMMARY
The level of gonadotrophin measured by radioimmunoassay in fully mature male goldfish was about $15 \mathrm{ng}$ carp gonadotrophic hormone (c-HG)/ $\mathrm{ml}$ plasma and $30 \mu \mathrm{g} \mathrm{c}-\mathrm{HG} / \mathrm{g}$ pituitary (wet weight). After treatment for 35 days with methallibure (added to the $v$ ier at the rate of 2 p.p.m./day), the level of gonadotrophin in the blood was very low and remained at the pretreatment level in the pituitary. This suggested that releasing factor might control either synthesis or discharge of gonadotrophin from the pituitary. These results have also shown that type B spermatogonia and meiosis were gonadotrophin dependent but that the development of spermatocytes into spermatids did not require high concentrations of gonadotrophin. Spermiation was suppressed when the concentration of c-HG dropped below $10 \mathrm{ng} / \mathrm{ml}$ plasma.
\end{abstract}

\section{INTRODUCTION}

Methallibure (ICI 33828) has been used to inhibit gonadotrophic function in mammals, e.g. rats (Paget, Walpole \& Richardson, 1961) and pigs (Garbers \& First, 1969; Polge \& Day, 1969). In fish, several workers have shown that the addition of methallibure to the water inhibited spermatogenesis in Gasterosteus acculeatus and Carassius auratus (Hoar, Wiebe \& Wai, 1967), Cymatogaster aggregata (Hoar et al. 1967; Wiebe, 1968, 1969) and Poecilia reticulata (Billard, Breton \& Jalabert, 1970; Martin \& Bromage, 1970; Pandey, 1970; Pandey \& Leatherland, 1970). When methallibure-treated goldfish were injected with carp whole pituitary extract, spermatogenesis resumed and spermiation (i.e. production of milt by stripping the male) occurred (Billard, Breton \& Escaffre, 1971). This suggested that methallibure exerts its inhibitory effect on the hypothalamo-pituitary system as in mammals (Polge \& Day, 1969) rather than upon the gonads. In an ultrastructural study, Leatherland (1969) showed that methallibure could block gonadotrophin synthesis.

In the present study a radioimmunoassay was used to determine the effect of methallibure on the level of gonadotrophin in the peripheral blood and pituitary. In addition the effects of methallibure on spermatogenesis were studied. 


\section{MATERIALS AND METHODS}

Sexually mature adult male Carassius auratus weighing $30-60 \mathrm{~g}$ and from the laboratory strain were used. The experiment started on $19 \mathrm{July} 1971$ and ended on 23 August 1971. Animals which had lived in a natural pond environment were placed, at the beginning of the experiment, in $150 \mathrm{l}$ aquaria with a photo-period of $14 \mathrm{~h}$ light: $10 \mathrm{~h}$ darkness (intensity: $400 \mathrm{~lx}$ at the bottom of each aquarium) and a constant temperature of $20^{\circ} \mathrm{C}$. Half the volume of water was renewed once a week. Methallibure (ICI 33828), added to the water every day at a dose of 2 p.p.m., was maintained in suspension by air bubbles.

Every 2, 3 or 4 days, five experimental animals were killed and blood samples were collected; in addition the pituitary and testes were removed. Samples were taken at the end of the experimental period from control animals which had been kept in the same environmental conditions as the treated ones. Gonadotrophin was measured in the plasma and pituitary by radioimmunoassay (Breton, Kann, Burzawa-Gérard \& Billard, 1971; Breton, Billard, Jalabert \& Kann, 1972), and quantitative analysis of spermatogenesis was performed according to the method of Billard, Solari \& Escaffre (1974). Type A spermatogonia refers to the spermatogonia which are not organized in cysts; type B spermatogonia refers to the ones organized in cysts.

\section{RESULTS}

\section{Spermatogenesis}

After 35 days, spermatogenesis in the control animals had progressed: the number of type $B$ spermatogonia, spermatocytes and spermatids decreased while the number of spermatozoa increased (Fig. 1).

After methallibure treatment the number of type A spermatogonia did not change but the number of type $B$ spermatogonia and spermatocytes decreased drastically within a few days. During the first 2 days of the experiment spermatids showed a temporary decrease in number while spermatozoa increased to a peak and then declined probably due to their development into spermatozoa. The number of every type of germinal cell except type A spermatogonia was significantly lower in the methallibure-treated fish than in the control fish. The degeneration of the germ cells started immediately after beginning the treatment as was shown by the number of pyknotic cells (Fig. 1). During the first 10 days, the volume occupied by Sertoli cells in treated fish was slightly smaller than in the control animals but the volume then increased and tended to be significantly higher than in the control animals (Fig. 2). The amount of connective tissue, which included interstitial cells, was not significantly different from the amount found in the control animals. Within 2 days the diameter of the lumina of the seminiferous tubules had decreased significantly (Fig. 3). The milt collected by stripping the male was normal in quantity up to the 10th day of treatment and then stopped, although large numbers of spermatozoa were still present in the seminiferous tubules.

The gonadosomatic index clearly reflected the changes in the output of spermatozoa (Fig. 3). 


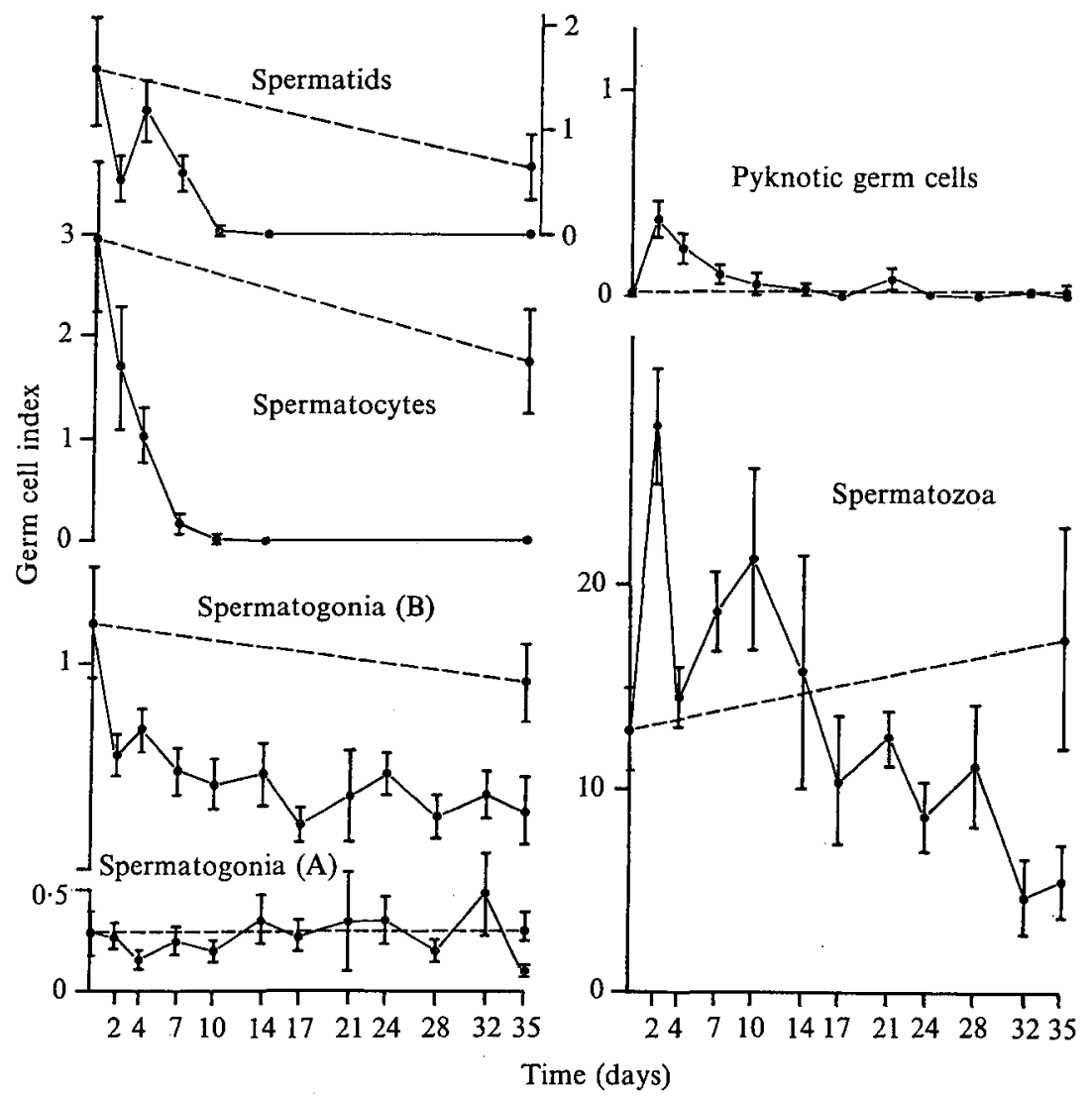

Fig. 1. Spermatogenesis in methallibure-treated (-) and control (--) goldfish. Germ cell index is the volume of germ cells expressed in $\mathrm{mm}^{3} /$ testes/g body weight. Spermatogonia (A) and (B) are spermatogonia types $A$ and $B$ respectively. The vertical lines indicate the s.E.M.
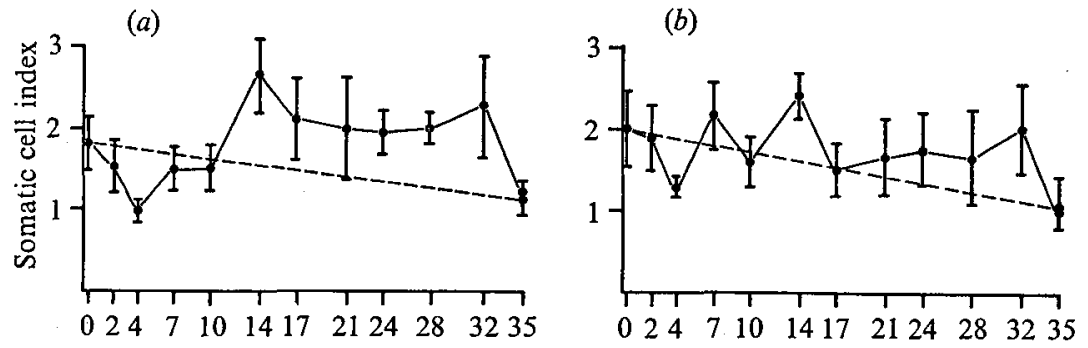

Time (days)

Fig. 2. Effects of methallibure treatment on somatic cells in the testes of goldfish. (a) Sertoli cells; (b) connective tissue (including interstitial cells). Experimental animals $(-)$, controls $(--)$; somatic cell index is the volume of somatic cells expressed as $\mathrm{mm}^{3} /$ testes/g body weight. The vertical lines indicate the S.E.M. 


\section{Gonadotrophin levels}

Plasma gonadotrophin levels (Fig. 4a) increased significantly within the first 2 days of treatment and then decreased very quickly. At the same time the gonadotrophin concentration in the pituitary was not significantly different from that in either control animals after 35 days or the initial level before treatment in the experimental group (Fig. $4 b$ ). In the control animals the level of gonadotrophin remained constant in the pituitary, and decreased, but not significantly, in the plasma by the end of the experimental period. The concentration of gonadotrophin in the pituitary of the treated animals was significantly lower than the level in the control animals.
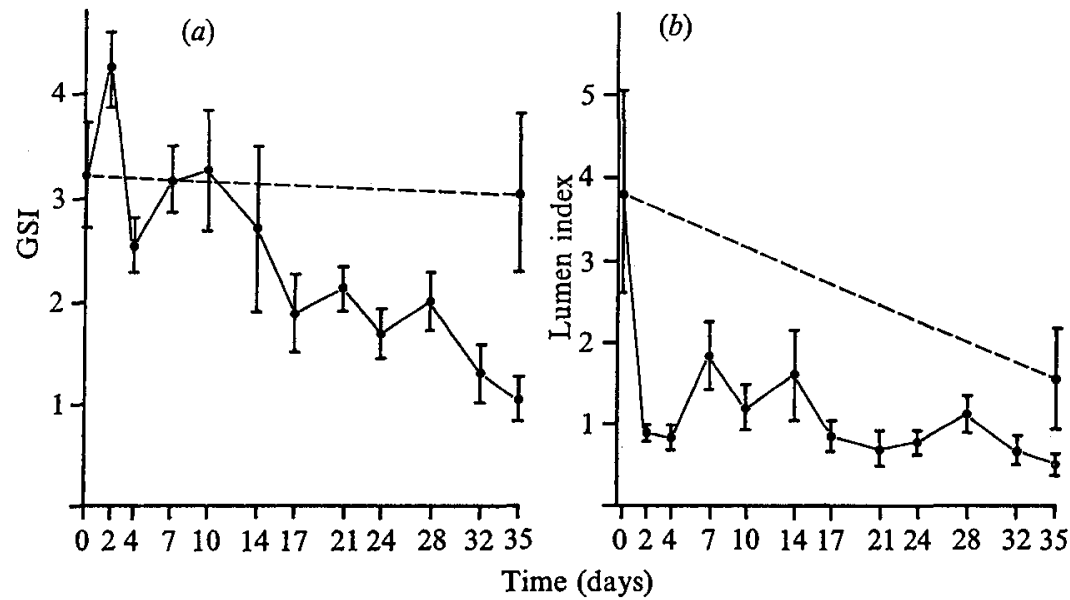

Fig. 3. Effects of methallibure treatment ( $a$ ) on goldfish gonadosomatic index (GSI) [GSI = (testis weight $\times 100$ )/body weight], and $(b)$ on the size of the seminiferous tubules. The seminiferous tubule lumen index is expressed by the volume of the lumen measured in the same way as that of germ cell and somatic cell (cf. Billard et al. 1974). Experimental animals (-); control animals (- ). The vertical lines indicate the S.w.M.

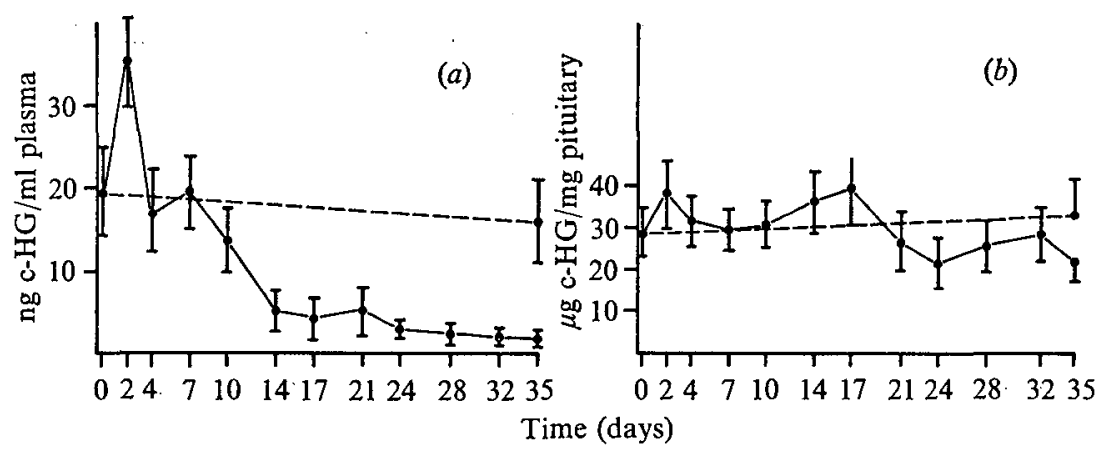

Fig. 4. Effect of methallibure treatment of goldfish on gonadotrophin concentration [expressed as standard carp gonadotrophic hormone (c-HG)] in (a) plasma and (b) pituitary. Experimental animals (-); control animals $(--)$. The vertical lines indicate the s.E.M. 


\section{DISCUSSION}

In methallibure-treated goldfish the number of type A spermatogonia did not change after treatments but the number of type $B$ spermatogonia seemed to be correlated with the plasma gonadotrophin level; first the number of type B spermatogonia decreased quickly as a result of stimulation by gonadotrophin and development into spermatocytes. The number of type $B$ spermatogonia remained at a low level. The number of primary spermatocytes also decreased and they developed into secondary spermatocytes and spermatids only when the gonadotrophin level in the plasma was above $10 \mathrm{ng} / \mathrm{ml}$. This suggested that gonadotrophin was necessary for the induction of meiosis. Conversely, low levels of carp gonadotrophin did not prevent the development of spermatids into spermatozoa.

These results confirm previous data on inhibition of spermatogenesis in goldfish after methallibure treatment (Billard et al. 1970). However, in the present study carried out during the spawning season, the number of spermatids decreased more rapidly than at the beginning of the spermatogenetic cycle.

Methallibure treatment caused a decrease in the level of gonadotrophin in the plasma and hence in its secretion from the pituitary. In addition, the synthesis of gonadotrophin was probably inhibited since we did not observe any increase in pituitary gonadotrophin concentration which would have occurred if methallibure had blocked only gonadotrophin release. In mammals some results suggest that methallibure may also inhibit follicle-stimulating hormone synthesis and secretion (Brown \& Fawke, 1972). Malven (1971) and Malven, Clemens \& Sawyer (1971) showed that methallibure prevented ovulation when implanted into the hypothalamus but not when implanted into the pituitary of female rats. In fish there is now strong evidence for hypothalamic control of gonadotrophin release from the pituitary (Peter, 1971; Breton, Jalabert, Billard \& Weil, 1971) and presumably methallibure inhibits gonadotrophin releasing factors.

In this study of goldfish during the last part of the spawning season, the plasma concentration of gonadotrophin was about $15 \mathrm{ng} / \mathrm{ml}$, that is, slightly higher than at the beginning of the spawning period in May (5-10 ng/ml; Breton et al. 1972). The level of gonadotrophin needed for spermiation was about $15 \mathrm{ng} / \mathrm{ml}$, since spermiation stopped after 10 days of treatment with methallibure when plasma gonadotrophin concentration dropped to almost $10 \mathrm{ng} / \mathrm{ml}$. The spermatozoa then remained in the testes and were phagocytosed by the Sertoli cells as shown previously (Billard \& Jalabert, 1972). This may explain the increase in the volume of the Sertoli cells which occurred after 10 days of treatment.

The increase in plasma gonadotrophin concentration immediately after the fish had been put into methallibure-treated water cannot be explained (Fig. 4a); Ajika, Kalra, Fawcett, Krulich \& McCann (1972) concluded that stress may induce a rapid release of gonadotrophins in rats. Although the period of increase of plasma gonadotrophin appeared to last longer in fish, it might have been induced by stress, e.g. animals being placed in a new environment and in a constant temperature instead of the natural thermoperiodism which might be important to these animals (Breton et al. 1972). 
This work was partly supported by a grant from Délégation Générale à la Recherche Scientifique et Technique (No. 71.7.3025). Methallibure was kindly provided by ICI Ltd. We wish to acknowledge the technical assistance of Mrs Anne-Marie Escaffre. Thanks are due to Dr P. G. McDonald for suggestions on the English presentation of the manuscript.

\section{REFERENCES}

Ajika, K., Kalra, S. O., Fawcett, C. O., Krulich, L. \& MoCann, S. M. (1972). The effects of stress and nembutal on plasma levels of gonadotrophins and prolactin in ovariectomized rats. Endocrinology $\mathbf{9 0}$, $707-715$.

Billard, R., Breton, B. \& Escaffre, A. M. (1971). Maintien et restauration de la spermatogenèse par un extrait acétonique hypophysaire de Carpe chez le cyprin (Carassius auratus) traité au méthallibure. Annls Biol. anim. Biochim. Biophys. 11, 167-174.

Billard, R., Breton, B. \& Jalabert, B. (1970). Inhibition de la spermatogenèse du guppy (Poisson Cyprino. dontidae) par le méthallibure. Annls Biol. anim. Biochim. Biophys. 10, 511-515.

Billard, R. \& Jalabert, B. (1972). Les cellules de Sertoli des poissons téléostéens. I. Etude ultrastructurale. Annls Biol. anim. Biochim. Biophys. 12, 19-32.

Billard, R., Solari, A. \& Escaffre, A. M. (1974). Les méthodes d'analyse quantitatives de la spermato. genèse des poissons téléostéens. Annls Biol. anim. Biochim. Biophys. 14 (In Préss).

Breton, B., Billard, R., Jalabert, B. \& Kann, G. (1972). Dosage radioimmunologique des gonadotropines plasmatiques chez Carassius auratus au cours du nyethémèré et pendant l'ovulation. Gen. comp. Endocr. 18, 462-468.

Breton, B., Jalabert, B., Billard, R. \& Weil, C. (1971). Stimulation in vitro de la libération d'hormone gonadotrope hypophysaire par un facteur hypothalamique chez la carpe Cyprinus carpio L. C. r. hebd. Séanc. Acad. Sci., Paris D 273, 2591-2594.

Breton, B., Kann, G., Burzawa-Gérard, E. \& Billard, R. (1971). Dosage radioimmunologique d'une hormone gonadotrope de carpe (Cyprinus carpio L.). C. r. hebd. Séanc. Acad., Paris 272, $1515-1517$.

Brown, P.S. \& Fawke, L. (1972). Effects of reserpine, $p$-chlorophenylalanine, $\alpha$-methyltyrosine, thymoxamine or methallibure on pituitary FSH in male rats. $J$. Reprod. Fert. 28, 167-175.

Garbers, D. L. \& First, N. L. (1969). The effects of injected oestradiol-17 $\beta$-progesterone and dietary ICI 33828 on ovarian and pituitary functions in the sow and gilt. J. Reprod. Fert. 20, 451-464.

Hoar, W. S., Wiebe, J. \& Wai, E. H. (1967). Inhibition of the pituitary gonadotropic activity of fishes by a dithiocarbamoyl-hydrazine derivative ICI 33828. Gen. comp. Endocr. 8, 101-109.

Leatherland, J. F. (1969). Studies on the structure and ultrastructure of the intact and 'methallibure' treated meso-adenohypophysis of the viviparous teleost Cymatogaster aggregata Gibbons. Z. Zellforsch. mikrosk. Anat. 98, 122-134.

Malven, P. V. (1971). Hypothalamic sites of action of methallibure (ICI 33828) inhibition of gonadotropin secretion. J. Anim. Sci. 32, 912-918.

Malven, P. V., Clemens, H. A. \& Sawyer, C. H. (1971). Inhibition of ovarian compensatory hypertrophy in the rat by intrahypothalamic implantation of methallibure. Endocrinology 88, 511-513.

Martin, P. \& Bromage, N. R. (1970). The effects of methallibure on spermatogenesis in Poecilia reticulata. J. Fish Biol. 2, 47-51.

Paget, G. E., Walpole, A. L. \& Richardson, D. N. (1961). Non-steroidal inhibitions of pituitary gonadotropic function. Nature, Lond. 192, 1191.

Pandey, S. (1970). Effects of methallibure on the testes and secondary sex characters of the adult and juvenile guppy Poecilia reticulata Peters. Biol. Reprod. 2, 239-244.

Pandey, S. \& Leatherland, J. F. (1970). Comparison of the effects of methallibure and thiourea on the testis, thyroid and adenohypophysis of the adult and juvenile guppy, Poecilia reticulata Peters. Can. $J$. Zool. 48, 445-450.

Peter, R. E. (1971). Feedback effects of thyroxine on the hypothalamus and pituitary of goldfish, Carassius auratus. J. Endocr. 51, 31-39.

Polge, C. \& Day, B. N. (1969). Induction of estrus and ovulation in swine during pituitary suppression with methallibure. J. Anim. Sci. 28, 73-75.

Wiebe, J. P. (1968). Inhibition of pituitary gonadotropic activity in the viviparous seaperch Cymatogaster aggregata Gibbons by a dithiocarbamoyl-hydrazine derivative ICT 33828. Can. J. Zool. 46, 751758.

Wiebe, J.P. (1969). Endocrine control of spermatogenesis and oogenesis in the viviparous seaperch Cymatogaster aggregata Gibbons. Gen. comp. Endocr. 12, 267-275. 